\title{
The effect of finger print absence and certification on the teachers performance
}

\author{
Diana Rosa $^{1}$, Muhammad Kristiawan ${ }^{2}$, YennyPuspita ${ }^{3}$ \\ ${ }^{1}$ Sekolah Menengah Pertama Negeri 12 Palembang, Indonesia \\ ${ }^{2}$ Universitas PGRI Palembang, Indonesia
}

\section{Article Info}

\section{Article history:}

Received Jul 20 $0^{\text {th }}, 2021$

Revised Aug $12^{\text {th }}, 2021$

Accepted Aug $30^{\text {th }}, 2021$

\section{Keyword:}

Finger print

Certification

Teachers performance

\begin{abstract}
This research was conducted to determine the effect of finger print attendance and certification on teacher performance. In this study, the population taken was the teacher who taught at SMP NegeriKertapati with a total sample of 69 people. The methodology used in this experiment is quantitative by reviewing the information obtained from the results of the distribution of the questionnaires to measures support across the district of 3 SMP NegeriKertapati. The information gathered to obtain a relationship between the variables observed and the sample in the 3 schools are also represented simultaneously by that kind of approach. Based on this information, it really is evident that: 1 . On teacher efficiency, there is an effect of finger print attendance, 2. Certification seems to have an impact on teacher performance, and 3. There is a shared impact on teacher competence at SMP NegeriSekecamatanKertapati between finger print attendance and certification. Teachers are expected to further develop their discipline and other competencies in the future, which will undoubtedly significantly improve success in the learning environment.
\end{abstract}

(C) 2021 The Authors. Published by IICET.

This is an open access article under the CC BY-NC-SA license

(https://creativecommons.org/licenses/by-nc-sa/4.0

\section{Corresponding Author:}

Kristiawan, M.,

Universitas PGRI Palembang, Indonesia

Email: muhammadkristiawan@unib.ac.id

\section{Introduction}

This research is focused on researchers findings while teaching at Palembang District SMP NegeriKertapati. The relevance of discipline, particularly in relation to the attendance of teachers at school. The continuity of the learning process is really facilitated by the participation of a teacher in regular activities at school.The presence of a teacher in daily activities at school really supports the continuity of the learning process. This is because what is faced by educators is not an inanimate object but a living object experiencing dynamics that we cannot predict every minute. The presence of educators in a timely manner greatly affects the condition of students in the classroom. This is in accordance with what the Government wants which is clearly regulated in the Government Regulation concerning Civil Servant Discipline Number 53 of 2010. This is because almost a large number of educators who are in State Junior High Schools are classified as State Civil Servants.

The use of absentee sheets as proof of teacher attendance has been implemented so far, however, there are still some weaknesses regarding the use of paper sheets as proof of attendance. The latest innovations are needed in order to improve the discipline of teachers and education personnel in schools so that there is no more news about teachers who do not pay attention to their students due to lack of discipline in their 
attendance in class. The new technology of attendance uses a finger print machine which is currently being used as evidence of a person's presence employees have been widely used in government and private agencies. However, recently this application is also used as evidence of teacher attendance at school

In addition to the timely attendance of teachers that educators must have in schools, teachers as a professional occupation also have recognition from the government which is manifested in the form of teacher certificates. This educator certificate is obtained by passing certain terms and regulations that have been set by the Government through the certification organizing agency. With these certain conditions, teachers who have certain competencies and things can get a certification allowance whose value is determined based on the class and length of service of each teacher.

Through the provision of this certification allowance, it is hoped that in addition to increasing the welfare of teachers and families, it is also able to improve teacher performance in implementing learning in schools.

Everything that is done by an educator as a form of action to support their work ability is a teacher's performance.Teacher performance is needed in order to carry out quality learning.Teacher performance is inseparable from motivational encouragement from the educators themselves, the influence of a good work environment is also a determining factor for the good performance of a teacher at school.

From some of the things above, the researcher wants to know whether the effect of the application of finger print attendance on the performance of the teachers of SMP Negeri Kertapati District Palembang, what is the effect of certification on the performance of teachers of SMP Negeri Kertapati Palembang andWhat is the effect of the application of finger print attendance and certification on the teacher performance of SMP Negeri Kertapati Palembang.

\section{Finger print absence}

Discipline in carrying out duties should be an obligation that must be carried out by each individual. An employee's discipline is a form of awareness of an employee in obeying the rules set by the institution where he serves [1]. The presence of educators is usually indicated by filling in an attendance sign called absences. Attendance itself is a record of activities and routines by an employee, in this case the teacher at school, which can be used as a guide or evidence for the teacher in implementing learning activities at school. This is in accordance with the function of an educator at school, which is to increase his / her ability so that it is necessary to use absences as a means of personal supervision as a form of controlling teacher attendance at certain periods at school [2]. [3]notes that attendance is indicative of the existence or presence of an employee while entering and leaving work hours. In carrying out its duties as an institution that facilitates teachers, students and student guardians, schools need educators who can carry out the mandate of the law that has been given to it. One of the benchmarks in the success of educational institutions is teacher discipline in school attendance. In accordance with their Main Duties and Functions as educators, the discipline of teachers in schools will certainly have an impact on the assessment of schools which are institutions where the teachers serve themselves by the surrounding community. Schools are usually located in an environment where there are people who can find out some of the activities carried out by the teacher, especially when they are still at school hours, but the teacher is still outside the school environment.

The Palembang City Government through the National Education Service as the institution in charge of Junior High Schools since the 2019/2020 school year has used finger print attendance as evidence of the presence of educators at schools. This is of course one of the major steps taken because so far, to record teacher attendance at school, only attendance written by the teacher has been used so that it cannot accurately measure the extent of daily teacher attendance at school. [4] in his research on the effect of finger print management and work motivation on improving teacher performance, it is found that there is a relationship between finger print management variables on the performance of MTsNGemolongSragen teachers.

Research [5] related to the effect of finger print attendance and work discipline concluded that fingerpritnt attendance and work discipline variables simultaneously had a positive influence on Teacher Performance at State Junior High Schools in SeberangUlu I District, Palembang. Fingerprint absence is a new method that is currently being developed using a software assisted machine that is currently being used to record a teacher's fingerprint data.

Dactyloscopy itself is the study of fingerprints Fingerprints, which are usually used to identify someone when a crime occurs, can now be used by using a fingerprint machine as a new method in the attendance system of educators.In general, the fingerprint function is to secure and also as a verification medium. 
[6] fingerprint attendance is a device used to record the date and time of entry and exit of employees through the fingerprinting of each employee. Schools as institutions that have the authority to monitor teacher attendance levels have prepared a fingerprint attendance machine as a substitute for old attendance.

This attendance uses an electronic machine as a tool. The fingerprint attendance machine is specially designed to use technology. These machines usually have a very large memory capacity and are also equipped with various features. Finger print attendance machines that have passed a series of trials are currently very appropriate to be applied in the world of education to help calculate teacher attendance. This tool will greatly help the human resource division, in this case school operators, to accumulate the number of teacher attendance to be used as material for the next teacher performance evaluation [4].

The advantages of using fingerprint as proof of attendance are as quoted through CenterKlik[7]which was accessed July 7, 2020 some of the advantages and disadvantages of fingerprint :1) Reducing the use of office stationery. 2)Increase the productivity of an office, in order to be present on time 3)Attendance data goes directly to the computer, and can be processed for attendance reports. 4) The level of cheating is relatively small, because everyone does not have the same fingerprint.

The weaknesses of using finger print as proof of presence are:1)Finger print machine prices are expensive 2) The fingerprint scan must be connected to electricity and the internet. 3)Fingerprint scanning is difficult to accept due to several factors, for example wet, dirty, peeled fingertips, too dry, abnormal finger conditions

\section{Certification}

There are many supporting factors in the school environment that can affect the amount of teacher performance. In addition to examining the effect of applying finger print attendance on other factors that will be further investigated, namely the effect of teacher certification on teacher performance. Teachers as State Civil Servants in carrying out their main duties and functions as professional staff must have certain competencies and qualifications, one of which is to have an educator certificate as a condition for obtaining certification allowances. According to the Law of the Republic of Indonesia Number 14 of 2005 certification is the process of granting teacher certificates to teachers and lecturers.

The process of granting certification is essential in an effort to obtain competency certificates in accordance with predetermined standards. This educational certificate is given to teachers who have met teacher professional standards. The teacher professional allowance is an allowance given to teachers who already have an educator certificate as a form of appreciation for the professionalism of the teacher [8]..

Certifications that have been given to teachers as educators are an effort to obtain professional educators in their work, so that in the future teachers will not only have certain competencies but also have social competence, personality competence, competence in their profession and academic competence [9]..

It's not the same as in the past,currently a person is deemed worthy of making a teacher as his profession if he holds a teacher certificate which indicates that he has met the requirements and criteria that must be met as a teacher.There are many standards that must be met by an educator in implementing learning in schoolsbased on the rules set by the Government.One of them is the teacher competency standard itself.

Based on the competencies possessed by the teacher, the teacher as much as possible is able to make it a means to develop the world of education to its full potential by continuously gaining insight in the field of education and technology. According to [8]. educators need to develop competencies that exist within the individual to the maximum in order to support progress in the world of education. In connection with the certification allowance that has been given by the government from 2006, in this case teachers must be able to take advantage of the allowances that have been given to teaching staff in addition to improving their welfare, especially to improve their performance as professional educators as a tangible form of responsibility for their work.

There are several steps that must be passed by a teacher before he / she is declared eligible for an educator certificate.Teachers who can take certification are teachers who have met the main requirements, namely having an academic diploma or minimum academic qualification of S-1 or equivalent. Teachers who teach not in accordance with their field of expertise can choose a certification process based on the S1 / D4 certificate they have, or choose a certification process based on the field of study being taught.

The purpose of providing certification based on the Ministry of National Education's guidebook is to determine whether a teacher is appropriate or not in carrying out his duties as a learning agent and realizing 
the goals of national education, improve the process and quality of educational outcomes,enhancing the dignity of the teacher also increases the professionalism of the teacher himself [11].

In connection with the certification allowance that has been provided by the government from 2006 so in this case the teacher must be able to take advantage of the allowances that have been given to teaching staff in addition to improving their welfareespecially to improve their performance as professional educators as a tangible form of responsibility for their work.

\section{Teachers performance}

Performance is part of the performance of an employee or employee when they carry out all the tasks that are the responsibility of the employee as long as they work in a certain place [9].. Furthermore, Fattah explained that there are many dimensions and indicators that affect the performance aspects of employees, this can be seen from the work results which are marked by the quantity and results of the work as well as the extent to which the level of work efficiency, work behavior is indicated by the presence of discipline and accuracy in carrying out their work and the last is the individual's personality which is indicated by the spirit of leadership and individual creativity.

Performance when viewed from a point of view [10]. is actually something someone's achievement. Performance can also be defined as the result of work both in terms of quality and quantity achieved by an employee in carrying out his duties in accordance with the responsibilities that have been given to him. This research is located in KertapatiDistrict, the location of the school is some distance from the city center with various stories about the people who live in it.

Researchers are interested in making State Junior High Schools located in Kertapati District the object of research because there has been no research on the extent of the effect of implementing finger print attendance and certification simultaneously on the performance of teachers who serve in State Junior High Schools in Kertapati DistrictPalembang.

\section{Method}

This research method uses quantitative research methods, namely a process of finding results using data in the form of numbers as a means of analyzing information about what you want to know [11].. Furthermore, according to [12]. the sample is part of the number of characteristics possessed by the population studied. The sample technique used according to Sugiyono, one of which is using the Non Probability Sampling technique using saturated sampling as a sampling technique using all members of the population in this case there are 69 people.The instrument in this study was a questionnaire. The data generated from distributing this questionnaire on an ordinal measurement scale using a Likert scale with a range of 1 to 5 and school documentation regarding fingerprint attendance as a supporting source of the instrument.

The data analysis techniques used in this study are : a. Normality testis a test conducted with the aim of assessing the distribution of data in a group of data so that it can be seen whether the data is normally distributed or not. b. Heteroscedasticity Test is a simple linear regression model data analysis technique is useful in knowing the extent of the influence of the independent variables, namely the application of fingerprint attendance (X 1) and (X2) certification on the dependent variable in this case the teacher performance (Y) of SMP Negeri Sekecamatan Kertapati Kota. Palembang. This research will be used to determine: 1. the effect between the application of finger print on the performance of teachers at SMP NegeriKertapati District Palembang, 2. the effect of certification on the performance of teachers at SMP NegeriKertapati District Palembang, and 3. the effect between the application of finger print and certification on the performance of teachers in SMP NegeriKertapatiDistrict Palembang.

\section{Results and Discussions}

Based on the research, several things were obtained below :

Multiple Correlation Statistical Analysis, shows that there is a relationship between the three variables, namely the Finger print attendance application variable $\left(\mathrm{X}_{1}\right)$ and the certification variable $\left(\mathrm{X}_{2}\right)$ on the teacher performance variable $(\mathrm{Y})$ with the correlation coefficient value in the following table 1: 
Table 1. Multiple Correlation Statistical Analysis Results and the Coefficient of Determination

\begin{tabular}{lllll}
\hline Model Summary & & & \\
Model & R & R Square & Adjusted R Square & $\begin{array}{l}\text { Std. Error of the } \\
\text { Estimate }\end{array}$ \\
\hline $\mathbf{1}$ & $.486^{\mathrm{a}}$ & 0,236 & 0,213 & 4,406 \\
\hline a. Predictors: (Constant), X2, X1 & & & \\
\hline b. Dependent Variable: $\mathbf{Y}$ & & & \\
\hline
\end{tabular}

From table $\mathrm{R}=0.486$ because the multiple correlation value is between $0.40-0.599$, itcan be concluded that there is a MEDIUM relationship between Fingerprint Attendance and Certification on Teacher Performance(Sugiyono, 2016)[12].

Analysis of the coefficient of determination, used to determine the percentage of the influence of the independent variables together on teacher performance variables. Regression with more than two independent variables is used as Adjusted as the coefficient of determination. Based on the table, the coefficient of determination $\mathrm{R}^{2}$ is 0.236 , which means that the application of finger print attendance and certification affects teacher performance $23.6, \%$ while the remaining $76.4 \%$ is explained by other factors.

Multiple Correlation Coefficients, often referred to as simultaneous hypothesis testing or F-test, are used to determine whether the regression coefficient together has a significant effect or not between finger print and certification variables on teacher performance variables. If the Sig. $<\alpha(0.05)$, then the regression coefficient is significant.

Table 2. F Test Statistical Analysis Results

\begin{tabular}{lllllll}
\hline \multicolumn{7}{c}{ ANOVA $^{\mathbf{a}}$} \\
\hline \multicolumn{1}{l}{ Model } & Sum of Squares & Df & Mean Square & F & Sig. \\
\hline $\mathbf{1}$ & Regression & 396,644 & 2 & 198,322 & 10,216 & $.000^{\mathrm{b}}$ \\
\cline { 2 - 7 } & Residual & 1281,298 & 66 & 19,414 & & \\
\cline { 2 - 7 } & Total & 1677,942 & 68 & & & \\
\hline
\end{tabular}

\section{a. Dependent Variable: $Y$}

\section{b. Predictors: (Constant), X2, X1}

Based on the explanation above, it is known that fcount $=10.216$ and ftable $=3.160$ where fcount $>$ ftable which means that $\mathrm{Ha}$ is accepted or in other words there is an effect of fingerprint attendance and certification on teacher performance.

Regression coefficient is often known as partial hypothesis testing or testing the effect of each independent variable on the dependent variable or in this study testing whether there is an effect of the finger print attendance application variable (X1) on teacher performance variables (Y) and certification variable (X2) on the teacher performance variable $(\mathrm{Y})$ by looking at the $\mathrm{t}$ value in the existing output.The results of testing the partial hypothesis can be seen in the table below:

Table 3. t-test statistical analysis results

\begin{tabular}{|c|c|c|c|c|c|c|}
\hline \multicolumn{7}{|c|}{ Coefficients $^{\mathrm{a}}$} \\
\hline \multicolumn{2}{|c|}{ Model } & \multicolumn{2}{|c|}{ Unstandardized Coefficients } & \multirow{2}{*}{$\begin{array}{c}\text { Standardized } \\
\text { Coefficients } \\
\text { Beta }\end{array}$} & \multirow[t]{2}{*}{$\mathrm{t}$} & \multirow[t]{2}{*}{ Sig. } \\
\hline \multirow{4}{*}{1} & & B & STlu. EITOI & & & \\
\hline & (Constant) & 31,124 & 12,653 & & 2,460 & 0,017 \\
\hline & $\mathrm{X} 1$ & 0,284 & 0,085 & 0,391 & 3,359 & 0,001 \\
\hline & $\mathrm{X} 2$ & 0,374 & 0,092 & 0,475 & 4,078 & 0,000 \\
\hline
\end{tabular}

a. Dependent Variable: $Y$

Based on the table 4.18 the coefficient, the tcount is obtained for 4.078. Hypothesis testing : 
tcount $>$ ttable $=$ alternative hypothesis $(\mathrm{Ha})$ Accepted

tcount $<\mathrm{t}$ table $=$ alternative hypothesis $(\mathrm{Ha})$ Rejected

The regression equation based on the coefficients table is as follows:

$\mathrm{Y}=31,124+0,284 \mathrm{X} 1+0,374 \mathrm{X} 2$

$\mathrm{Y}=$ Teacher performance

$\mathrm{X} 1=$ Fingerprintabsence

$\mathrm{X} 2$ = Certification

When the regression equation is described above, it means:The resulting constant value is 31,124 , this means that if there are no fingerprint attendance and certification variables, the teacher performance score is 0.284 . So on a scale of 2 it is categorized as good.If the fingerprint attendance variable (X1) increases, the teacher performance score will increase or increase by 0.284 provided that the certification (X2) is constant. If the value resulting from the certification variable (X2) increases or increases, the teacher performance variable $(\mathrm{Y})$ will increase or increase by 0.374 provided that the fingerprint attendance variable (X1) is constant.

The Effect of Finger print Attendance (X1) on Teacher

Performance $(\mathrm{Y})$

Based on the data obtained from the research results show that Finger print attendance has a significant effect on teacher performance. These results support the proposed hypothesis in which there is a significant influence between the application of finger print attendance significantly on teacher performance.

Regarding whether there is a significant influence between fingerprint absenteeism (X1) on teacher performance $(\mathrm{Y})$, it can be seen in the value of the tcount shown in table 4.18. The $t$-count value of fingerprint attendance is 3.359 with a significant value of $0.000(\mathrm{p}<0.05)$ with a t table of 1.420 or in other words tcount> $\mathrm{t}$ table, then Ho rejects and accepts $\mathrm{Ha}$ or in other words this shows that there is a significant influence between fingerprint attendance ( X1) on Teacher Performance (Y).

Obtaining data from some of the findings of the researchers above shows that there is a significant influence between the application of finger print attendance on teacher performanceThis is evidenced by the data obtained from the results of data processing by a series of processes and tests that are relevant in accordance with existing regulations. Finger print attendance as an application of the attendance list which is quite new to be introduced to educational institutions, especially in the Palembang City Education Office, has an effect on the performance of teachers of SMP Negeri Kertapati Palembang.

\section{The Effect of Certification (X2) on Teacher}

\section{Performance $(\mathrm{Y})$}

The results showed that certification can affect teacher performance. When looking at the regression results based on the table and proven by the value of the certification variable (X2), the teacher's performance $(\mathrm{Y})$ will increase by 4.078 , provided that the finger print attendance value (X1) is constant.Regarding whether there is a significant influence between certification on teacher performance based on the table, it is obtained that the tcount of certification variable (X2) is 4.078 with a significant level of 0.000 where $\rho<0.05$, we can conclude that There is a significant effect between certification (X2) on teacher performance (Y) in SMP Negeri, which means that the alternative hypothesis or Ha is accepted, while Ho is rejected.

This research is supported by the results of previous research conducted by Khusnaini (2015)[16], the results of his research concluded that teacher certification has an effect on the performance of teachers at Madrasah Ibtidaiyah (KKMI) at the level of Limpung District, Batang Regency.

Previous studies have shown that there is an effect of certification on teacher performance. Certification is a professional allowance provided by the government with the aim of not only improving teacher welfare but also increasing teacher competence in accordance with changes in the field of education.

With the desire of educators to increase competence beyond their capabilities so far, it should be used as an assessment of the competent authorities so that they also support other facilities and infrastructure that can be used to develop the world of education optimally. Educators are given support so that it can be realized in more strategic steps, of course, by prioritizing the quality of learning rather than just prioritizing quantity especially if it is just for carrying out tasks alone. 
Hence the implementation of Finger print attendance and certification is expected to contribute greatly to teacher performance. This is not unreasonable, because so far the teachers are still struggling with tasks that are continuously flowing so that the time they have is running out for this. Routine activities that must be carried out not only at school but also at home clearly make some teachers lack time to develop themselves professionally to increase their performance on duty.

In conditions like this the teacher should be aware that with the application of attendance using finger print-based technology, the teacher can be more responsible for discipline and for their work. Teachers minimize things that can reduce their performance on duty. Efforts to increase teacher professionalism and teacher performance through the certification allowance program as a form of government appreciation for the welfare of teachers because teachers are the front guard in supporting education. Through this certification allowance program, teachers must think of ways and steps to develop themselves because one of the elements that is considered in the provision of certification allowances is self-development.

Self-development is one of the greatest elements of assessment that the government hopes to find out about the level of quality and worthiness of a teacher in carrying out the learning process at school. The government's efforts to improve teacher professionalism must be welcomed by teachers by prioritizing teacher performance in schools.

Teachers need to develop a sense of love for the teaching profession that exists within them as well as a sense of nationalism that grows within us. The government must also realize that certification is one way to further improve teacher professionalism so that a good performance is obtained in the world of education.

Providing certification is the government's first step in the form of professional recognition of a teacher. This of course must be accompanied by another system of continuous improvement of teacher professionalism, because without other matters relating to this, of course teacher certification will have less impact on teacher performance and other matters related to improving the quality of education.

\section{Conclusions}

From the data that has been obtained in this study, there are several conclusions that the researchers can take, namely that there is an effect of the application of finger print attendance on the performance of SMP NegeriKertapati District Palembang teachers, there is an effect of certification on the performance of teachers of SMP NegeriKertapati District Palembang, there is also a joint influence between the application of attendance. finger print and certification of teacher performance at SMP NegeriKertapati DistrictPalembang. As a follow-up to this research, teachers should be more open in accepting new technologies in the educational environment.Through the application of finger print as a new technology it can also make it easier for teachers when doing attendance so that their performance is better and for school operators it can make it easier to recapitulate attendance data more accurately. The provision of a certification allowance from the Government should really be able to bring about changes for teachers both in terms of welfare and performance in schools.To the authorities, they should be able to be on time in providing professional allowances for teaching personnel because teachers have shown their competence in efforts to improve teacher performance so that the Government's goals for the welfare of teachers and improving the quality of education can be achieved.

\section{References}

Handoko T; Hani. (2012). Manajemen Sumber Daya Manusia. Yogyakarta: BPFE.

Kristin L.S; Suputra I.N; Sarbini. (2016). Pengaruh Penerapan Presensi Sidik Jari (Fingerprint) TerhadapKinerja Guru Melalui Motivasi Kerja di SMA Negeri 5 Malang. Jurnal Pendidikan Bisnis dan Manajemen, Vol. 2, No. 3 November, 170-177.

Kasmir. (2016). ManajemenSumberDayaManusiaTeoridanPraktik. Jakarta: RajaGrafindoPersada.

H.S, M. (2015). Manajemen Finger Print dan Motivasi Kerja Terhadap Peningkatan Kinerja Guru MTsNGemolongSragen. Surakarta: IAIN.

Dameria, N. (2019).Pengaruh Absensi Fingerprint dan Disiplin Kerja Terhadap Kinerja Guru SMP Negeri Di Kecamatan SeberangUlu I District, Palembang. Palembang. Palembang: UNIVERSITAS PGRI.

Topik, M. (2010). Panduan Praktis Membuat Aplikasi Penggajian Dengan Excel. Jakarta: Media Kita.

https://www.centerklik.com.Kelebihanfingerpritnt. (akses 7 juli 2020)

Kartini, D., \& Kristiawan, M. (2019). Pengaruh Tunjangan Profesi dan Motivasi Kerja Terhadap Kinerja Guru. Kelola: Jurnal Manajemen Pendidikan, 6(1), 25-33.

Nuh, M. (2012, Juni 5). Pengadaan Guru Akan Lebih Selektif. Dipetik Juli 5, 2020, dari https://republika.co.id. 
Sulistyo (2015) Ketika Sertifikasi Santer digunjing. Suara Guru(7)

Zulaekha, Nur. 2011. PanduanSukses Lulus Sertifikasi Guru. Yogyakarta: Pinus Book Publisher

Fattah, A. H. (2019). Kepuasan Kerja Dan Kinerja Pegawai. Yogyakarta: Penerbit Elmatera.

Mangkunegara. (2010). Evaluasi Kinerja Sumber Daya Manusia. Bandung:Refika Aditama.

Kasiram. (2008). Metodologi Penelitian Kualitatif-Kuantitatif. Malang: Maliki Press.

Sugiyono. (2016). Metode Penelitian Manajemen. Bandung: AlfaBeta.

Khusnaini, M.(2015) Pengaruh Sertifikasi Guru Dan Motivasi Kerja Guru Terhadap Kinerja Guru Di KKMI Tingkat Kecamatan Limpung Kabupaten Batang. Semarang: UNIVERSITAS PGRI . 